\title{
GROWTH PERFORMANCE AND NUTRITIONAL VALUE OF Scenedesmus obliquus CULTURED IN DIFFERENT CONCENTRATIONS OF SWEETMEAT FACTORY WASTE MEDIA
}

\author{
M. A. Toyub ${ }^{1}$, M. I. Miah ${ }^{2}$, M. A. B. Habib ${ }^{3}$ and M. M. Rahman ${ }^{4}$
}

\begin{abstract}
The growth performance of Scenedesmus obliquus was studied in the laboratory in different concentration of sweetmeat factory waste media (SFWM). Four different concentrations viz. 1.5, 2.0, 2.5 and $3.0 \%$ of SFWM and Bold basal medium (BBM) as control was used with three replications for a period of three months. Each trial was done for a period of 14 days in the laboratory. The initial density of Scenedesmus obliquus was $2.1 \times 10^{5}$ cell $/ \mathrm{ml}$ which attained a maximum density of $136.30 \times 10^{5} \mathrm{cell} / \mathrm{ml}$ in BBM followed by $97.05,83.21,65.19$ and $51.21\left(\times 10^{5} \mathrm{cell} / \mathrm{ml}\right)$ in $2.5,0.3,2.0$ and $1.5 \%$ SFWM respectively on the $10^{\text {th }}$ day of culture. Highest chlorophyll a content was also observed on the $10^{\text {th }}$ day of culture with value of 6.14 and $5.52 \mathrm{mg} / \mathrm{l}$ in BBM and SFWM, respectively. The specific growth rate (SGR, $\mu /$ day $)$ and total biomass were significantly $(\mathrm{P}<0.05)$ higher in $\mathrm{BBM}$ than all other treatments. The overall growth performance of the alga Scenedesmus obliquus was significantly $(\mathrm{P}<0.05)$ higher in $2.5 \%$ SFWM than other concentrations of SFWM. The cultured microalgae were found nutritionally rich. During the whole culture period the $\mathrm{pH}$ range was 7.03 to 8.05 . The other physico-chemical parameters of the culture media were found within the suitable range of the microalgae culture.
\end{abstract}

Key words : Sweetmeat factory waste, Scenedesmus obliquus, Chlorophyll a

\section{Introduction}

Microalgae is one of the main live foods for rotifers, cladocerans and other zooplanktons as well as larvae of fish and shrimp (Gallardo et al., 1995). From the nutritional point of view, it is well established that many freshwater and marine microalgae play vital role in supplying energy, essential nutrients, such as protein, lipid, carotene, vitamins, amino acids, polyunsaturated fatty acids and essential minerals for proper development of aquatic organisms (Geldenhuys et al., 1988; Vymazal, 1995; Yamaguchi, 1997; Habib et al., 2003). Inorganic media were used in most of the early experimental works to grow algae (Shelef et al., 1978). It was reported that the estimated cost of nutrients and $\mathrm{CO}_{2}$ in utilizing wastewater is not needed. Agricultural, agro-industrial and municipal wastes contain all the macro and micro-nutrients important for algal growth. Thus it is economical to produce microalgae in wastewater. However, both inorganic and organic nutrients give very good growth rate of alga species in the laboratory (Hemerick, 1973) where the most successful genera are Chlorella, Scenedesmus and Ankistrodesmus (Rodhe, 1978). Scenedesmus contains all the essential

\footnotetext{
${ }^{1}$ Department of Fisheries, Ministry of Fisheries and Livestock, Bangladesh

${ }^{2}$ Professor, ${ }^{4} \mathrm{Ph}$.D. Fellow, Department of Fisheries Management, Bangladesh Agricultural University, Mymensingh-2202, Bangladesh

${ }^{3}$ Professor, Dept. of Aquaculture, Bangladesh Agricultural University, Mymensingh-2202, Bangladesh
}

(Received : June 01, 2008) 
Bang. J. Anim. Sci. 2008, 37 (1)

amino acids and a good amount of protein, lipid and mineral content (Geldenhuys et al., 1988). In Bangladesh, freshwater microalgae as Scenedesmus obliquus may contribute a great extent as health foodstuffs as well as live food development for aquaculture. The present study was undertaken to produce $S$. obliquus in different concentrations of sweetmeat factory waste media and also to know the nutritional values of the microalgae thus produced.

\section{Materials and Methods}

\section{Research institute}

The experiment was conducted at the Live Food Culture Laboratory, Department of Aquaculture, Bangladesh Agricultural University, Mymensingh. The experiment was conducted from 15 June to 15 September 2005. The equipments, chemicals and other facilities available at the Faculty were also used whenever required.

\section{Collection and preparation of sweetmeat factory waste media}

Sweetmeat waste was collected from Mymensingh town. It was diluted with distilled water to 1.5, 2.0, 2.5 and $3.0 \%$ concentration levels and was fermented for one month by aeration at room temperature. The supernatant of fermented media was filtered. Urea was added at the rate of $0.2 \mathrm{~g} / \mathrm{l}$ to increase nitrogen content of the media. Then the media was mixed well and sterilized at $120^{\circ} \mathrm{C}$ for 15 minutes with moist heat by autoclave. Bold basal medium (BBM) was used as control media. Composition of BBM is shown in Table 1.

Table 1. Composition of Bold basal medium (BBM) for Scenedesmus obliquus culture

\begin{tabular}{|c|c|c|}
\hline Chemicals/ Compounds & $\begin{array}{c}\text { Concentration in stock } \\
\text { solution }\left(\mathrm{g} \cdot \mathrm{I}^{-1}\right)\end{array}$ & Amount in culture medium $\left(\mathrm{ml} \mathrm{l}^{-1}\right)$ \\
\hline $\mathrm{NaNO}_{3}$ & 25.00 & 10.0 \\
\hline $\mathrm{MgSO}_{4} \cdot 7 \mathrm{H}_{2} \mathrm{O}$ & 7.50 & 10.0 \\
\hline $\mathrm{NaCI}$ & 2.50 & 10.0 \\
\hline $\mathrm{K}_{2} \mathrm{HPO}_{4}$ & 7.50 & 10.0 \\
\hline $\mathrm{KH}_{2} \mathrm{PO}_{4}$ & 17.50 & 10.0 \\
\hline $\mathrm{CaCI}_{2} 2 \mathrm{H}_{2} \mathrm{O}$ & 2.50 & 10.0 \\
\hline Trace element & & 1.0 \\
\hline a) $\mathrm{ZnSO}_{4} \cdot 7 \mathrm{H}_{2} \mathrm{O}$ & 8.82 & - \\
\hline b) $\mathrm{MnCl}_{2 .} 4 \mathrm{H}_{2} \mathrm{O}$ & 1.44 & - \\
\hline c) $\mathrm{MoO}_{3}$ & 0.71 & - \\
\hline d) $\mathrm{CuSO}_{4} \cdot 5 \mathrm{H}_{2} \mathrm{O}$ & 1.57 & - \\
\hline e) $\mathrm{Co}\left(\mathrm{NO}_{3}\right)_{2} \cdot 6 \mathrm{H}_{2} \mathrm{O}$ & 0.94 & - \\
\hline $\mathrm{H}_{3} \mathrm{BO}_{3}$ & 11.40 & 1.0 \\
\hline EDTA-KOH solution & & 1.0 \\
\hline a) EDTA $\mathrm{Na}_{2}$ & 50.00 & - \\
\hline b) $\mathrm{KOH}$ & 31.00 & - \\
\hline $\mathrm{FeSO}_{4 .} 7 \mathrm{H}_{2} \mathrm{O}$ & 4.98 & 10 \\
\hline Conc. $\mathrm{H}_{2} \mathrm{SO}_{4}$ & $1.0 \mathrm{ml}^{\cdot} \mathrm{l}^{-1}$ & 1.0 \\
\hline
\end{tabular}


Use of sweetmeat factory waste media for fish culture

\section{Culture of Scenedesmus obliquus}

Stock culture of Scenedesmus obliquus maintained in the Department of Aquaculture, Bangladesh Agricultural University, Mymensingh was used for this study. The cells were separated with the help of microcapillary through different dilutions using compound microscope. Scenedesmus obliquus was inoculated initially in prepared BBM. Five treatments, four from different concentrations (1.5, 2.0, 2.5 and 3.0\%) of SFWM and one from BBM (control) were used to grow the microalgae, Scenedesmus obliquus in 1.0 liter volumetric flask with three replications for each treatment. The microalgae were inoculated into each culture flask from the stock (Optical density at $620 \mathrm{~nm}=0.20)$ (Habib, 1998) to get $10 \%$ suspension of Scenedesmus obliquus. All the flasks were kept under fluorescent lights (light: dark $=12 \mathrm{~h}: 12 \mathrm{~h}$ ) in the Live Food Culture Laboratory. The culture flasks were continuously aerated using electric aerator. Samplings were carried out at every alternate day from each flask to observe cell density, chlorophyll a, optical density and physico-chemical properties of culture media and physico-chemical properties were recorded viz. temperature, light intensity, dissolved oxygen (DO), $\mathrm{pH}$, nitrate-nitrogen, nitrite-nitrogen, ammonia-nitrogen and phosphate- phosphorus. All the glass wares used in the experiment were sterilized with dry heat in an oven at $70^{\circ} \mathrm{C}$ for overnight.

\section{Estimation}

\section{Physico-chemical properties of culture media}

Temperature, light intensity, dissolved oxygen and $\mathrm{pH}$ were determined by respective meters. Nitritenitrogen, nitrate-nitrogen and phosphate-phosphorus were determined by Hach kit (DREL/2000) following Clesceri et al. (1989).

\section{Scenedesmus obliquus cell density}

Scenedesmus obliquus cells were counted using an improved Neubauer ruling haemacytometer and cell density of algal culture were estimated according to the following formula (Clesceri et al., 1989):

No. of cells $1^{-1}=\frac{\text { No. of cell counted in } 16 \text { chamber }}{10^{-4}} \times$ dilution factor

\section{Chlorophyll $\underline{a}$}

Optical densities of the prepared samples were determined at 664,647 and $630 \mathrm{~nm}$ wave length by using UV spectrophotometer. A blank with $100 \%$ acetone was run simultaneously. Chlorophyll a content was calculated by the following formula (Clesceri et al. 1989) :

Chlorophyll $\underline{\mathrm{a}}(\mathrm{mg} / \mathrm{l})=11.85$ (OD 664)-1.54 (OD 647)-0.08 (OD 630).

\section{Specific growth rate (SGR, $\mu$ / day) of microalgae}

The specific growth rate (SGR $\mu \mathrm{g} /$ day) of cultured microalgae was calculated by the following equation (Clesceri et al., 1989) :

$\operatorname{SGR}(\mu \mathrm{g} /$ day $)=\ln \left(\mathrm{X}_{1}-\mathrm{X}_{2}\right) / \mathrm{t}_{2}-\mathrm{t}_{1}$

Where,

$\mathrm{X}_{1} \quad=$ Biomass concentration at the end of selected time interval

$\mathrm{X}_{2}=$ Biomass concentration at the beginning of selected time interval, and

$\mathrm{t}_{2}-\mathrm{t}_{1}=$ Elapsed time between selected time in the day. 
Bang. J. Anim. Sci. 2008, 37 (1)

\section{Analysis of proximate composition}

Proximate compositions of mass cultured algal samples were analyzed in the nutrition laboratory, Department of Aquaculture, Faculty of Fisheries, Bangladesh Agricultural University, following standard methods (Horwitz, 1984).

\section{Statistical analysis}

Mean and standard deviation were calculated from the experimental data. Then the data were analyzed through one-way analysis of variance (ANOVA) using SPSS followed by Duncan's Multiple Range Test (DMRT) to assure significant difference among the treatment means (Zar, 1984).

\section{Results}

The maximum cell number $136.30 \times 10^{5} / \mathrm{ml}$ of Scenedesmus obliquus was found in control BBM followed by $2.5,0.3,2.0$ and $1.5 \%$ SFWM (Fig. 1) on the $10^{\text {th }}$ day of the culture. Similar trend was observed in the case of chlorophyll a content with values $6.14,5.52,4.77,3.61$ and $2.71 \mathrm{mg} / 1$, respectively (Fig. 2). Optical density was recorded in the range of 0.81 to 1.64 at $620 \mathrm{~nm}$ wavelength. The specific growth rate (SGR, $\mu \mathrm{g} /$ day) of cell and chlorophyll a were recorded in the range of 0.32 to 0.42 and 0.33 to 0.41 , respectively for all the treatments. Total biomass of $S$. obliquus in respect to chlorophyll a content was recorded in the range of 181.57 to $411.16 \mathrm{mg} / \mathrm{l}$. It was found maximum when grown in BBM followed by 2.5, 0.3, 2.0 and 1.5\% SFWM (Table 2). The $\mathrm{pH}$ of the media increases with the age of culture and on $10^{\text {th }}$ day, it ranged from 7.61 to 7.88 for all the treatments (Fig. 3). An increasing trend of dissolved oxygen was observed up to the stationary phase $\left(10^{\text {th }}\right.$ day) and next it decreases. Dissolved oxygen was recorded in the range of 2.90 to $5.47 \mathrm{mg} / \mathrm{l}$ during the whole culture period.

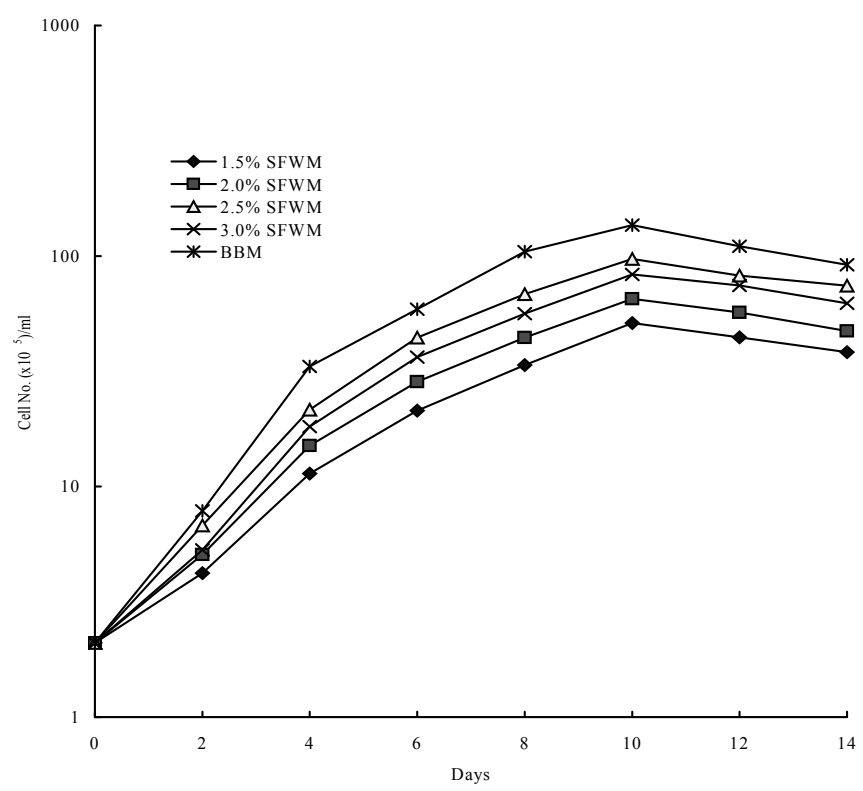

Fig. 1. Semilogarithmic growth curves based on cell number $\left(\times 10^{5}\right) / \mathrm{ml}$ of Scenedesmus obliquus grown in different concentration of SFWM and BBM 
Use of sweetmeat factory waste media for fish culture

Table 2. Mean ( $\pm \mathrm{SD})$ of specific growth rate $(\mu \mathrm{g} / \mathrm{day})$ of cell, chlorophyll a (chlo-a) and total biomass (mg/l) of Scenedesmus obliquus grown in different concentrations of SFWM and BBM

\begin{tabular}{l|l|l|l|l|c}
\hline \multicolumn{1}{c}{ Parameters } & \multicolumn{1}{c}{$\mathbf{1 . 5 \%}$ SFWM } & \multicolumn{1}{c|}{$\mathbf{2 . 0 \%}$ SFWM } & $\mathbf{2 . 5 \%}$ SFWM & 3.0\% FWM & \multicolumn{1}{c}{ BBM } \\
\hline SGR of cell & $0.32^{\mathrm{d}} \pm 0.01$ & $0.34^{\mathrm{c}} \pm 0.01$ & $0.38^{\mathrm{b}} \pm 0.01$ & $0.37^{\mathrm{b}} \pm 0.01$ & $0.42^{\mathrm{a}} \pm 0.01$ \\
SGR of chlo- $\underline{\mathrm{a}}$ & $0.33^{\mathrm{d}} \pm 0.01$ & $0.36^{\mathrm{c}} \pm 0.01$ & $0.40^{\mathrm{a}} \pm 0.01$ & $0.39^{\mathrm{b}} \pm 0.01$ & $0.41^{\mathrm{a}} \pm 0.01$ \\
$\begin{array}{l}\text { Total biomass } \\
\text { (Chlo- } \underline{\mathrm{a}} \text { x 67) }\end{array}$ & $181.57^{\mathrm{c}} \pm 18.87$ & $241.87^{\mathrm{d}} \pm 20.44$ & $369.84^{\mathrm{b}} \pm 27.49$ & $319.37^{\mathrm{c}} \pm 19.70$ & $411.16^{\mathrm{a}} \pm 24.20$ \\
\hline
\end{tabular}

${ }^{\text {abd }}$ Means with different superscripts(s) in the same row differ significantly $(\mathrm{P}<0.01)$

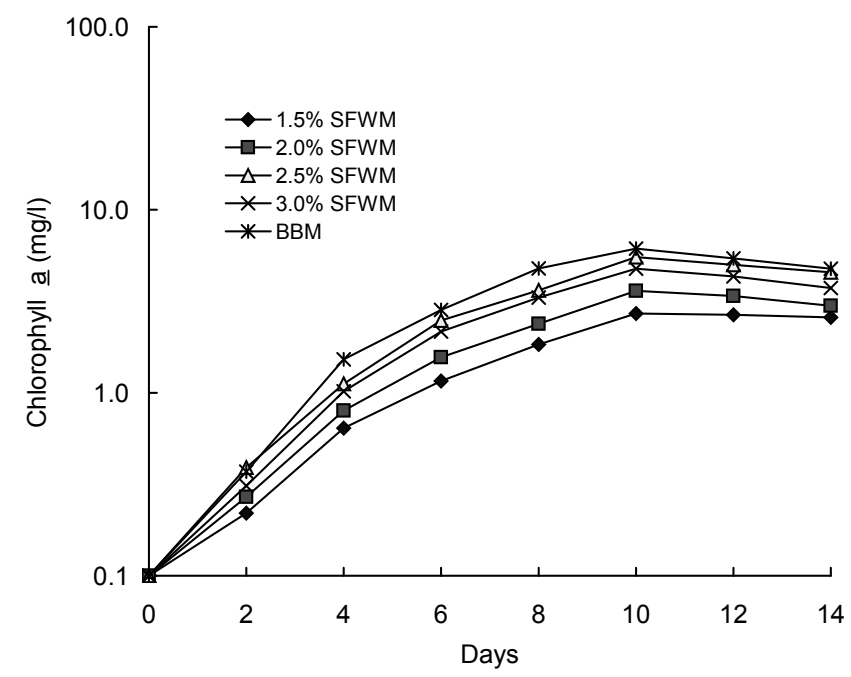

Fig. 2. Semilogarithmic growth curves based on chlorophyll a content (mg/l) of Scenedesmus obliquus grown in different concentration of SFWM and BBM

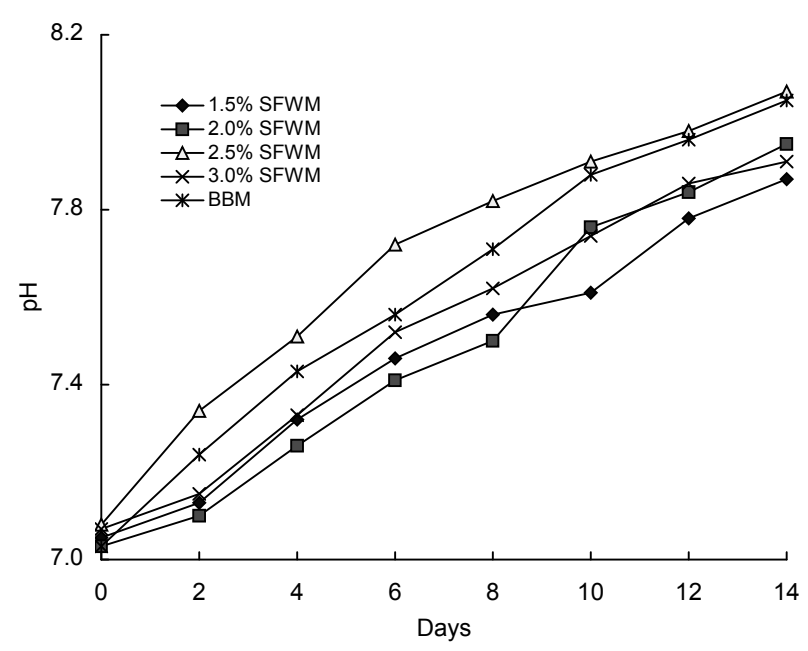

Fig. 3 pH of different concentration of SFWM and BBM containing Scenedesmus obliquus 
Bang. J. Anim. Sci. 2008, 37 (1)

At the beginning of the culture $\mathrm{PO}_{4}-\mathrm{P}$ was the highest in BBM $(7.16 \mathrm{mg} / \mathrm{l})$ followed by $1.5,2.0,2.5$ and $3.0 \%$ SFWM. But on the $10^{\text {th }}$ day of culture when the growth of Scenedesmus obliquus was peak it was recorded 1.62, 1.75, 2.16, 2.34 and $4.06 \mathrm{mg} / 1$ in 1.5, 2.0, 2.5, 3.0\% SFWM and BBM, respectively. The range of $\mathrm{NO}_{3}-\mathrm{N}$ content was recorded 2.31 to $9.54 \mathrm{mg} / \mathrm{l}$ at the beginning and 1.02 to $4.16 \mathrm{mg} / \mathrm{l}$ on the peak period of cell growth. In both cases highest content was recorded in BBM. On the other hand $\mathrm{NO}_{2}-\mathrm{N}$ showed an increasing trend with the age of culture and a little content was recorded throughout the culture period. At the stationary phase it was found 0.05 to $0.09 \mathrm{mg} / \mathrm{l}$ for all the treatments including BBM. The content of $\mathrm{NH}_{3}-\mathrm{N}$ also showed an increasing trend with the age of culture and the range was 0.14 to $0.81 \mathrm{mg} / \mathrm{l}$ for all treatments when cell density was the maximum. At that period the highest content of $\mathrm{NH}_{3}-\mathrm{N}$ was recorded in $2.5 \% \mathrm{SFWM}$ and the lowest content was recorded in BBM. During the study period the temperature range was 28.90 to $29.37^{\circ} \mathrm{C}$ and the range of light intensity was recorded 2137.28 to $2176.14 \mathrm{lux} / \mathrm{m}^{2} / \mathrm{s}$.

The highest percentage of protein 34.93 was recorded for BBM followed by 2.5, 3.0, 2.0 and 1.5\% SFWM. On the other hand crude fiber was more or less similar for all the treatments and the range was 6.39 to $6.59 \%$. However, crude lipid, ash, moisture and NFE were ranged from 12.64 to $16.137 \%$, 9.95 to $12.08 \%, 8.67$ to $9.14 \%$ and 22.36 to $29.75 \%$ respectively, for all the treatments including BBM (Table 3).

Table 3. Mean values $( \pm \mathrm{SD})$ of proximate composition $(\%)$ of Scenedesmus obliquus cultured in different concentrations of SFWM and BBM

\begin{tabular}{|l|c|c|c|c|c|}
\hline Composition & $\mathbf{1 . 5 \%}$ SFWM & $\mathbf{2 . 0 \%}$ SFWM & $\mathbf{2 . 5 \%}$ SFWM & $\mathbf{3 . 0 \%}$ SFWM & BBM \\
\hline Crude protein & $28.30^{\mathrm{d}} \pm 1.17$ & $30.28^{\mathrm{c}} \pm 1.18$ & $334.56^{\mathrm{a}} \pm 1.12$ & $32.68^{\mathrm{b}} \pm 1.12$ & $34.93^{\mathrm{a}} \pm 0.63$ \\
Crude lipid & $12.64^{\mathrm{c}} \pm 0.38$ & $114.04^{\mathrm{b}} \pm 0.40$ & $16.13^{\mathrm{a}} \pm 0.85$ & $13.15^{\mathrm{c}} \pm 0.58 \mathrm{~b}$ & $14.33^{\mathrm{b}} \pm 1.03$ \\
Ash & $110.29^{\mathrm{b}} \pm 0.05$ & $10.75^{\mathrm{b}} \pm 0.58$ & $12.08^{\mathrm{a}} \pm 0.36$ & $9.95^{\mathrm{b}} \pm 0.54$ & $11.72^{\mathrm{a}} \pm 0.46$ \\
Crude fiber & $6.40^{\mathrm{a}} \pm 0.21$ & $6.50^{\mathrm{a}} \pm 0.36$ & $6.39^{\mathrm{a}} \pm 0.18$ & $6.59^{\mathrm{a}} \pm 0.42$ & $6.46^{\mathrm{a}} \pm 0.09$ \\
Moisture & $8.78^{\mathrm{a}} \pm 0.17$ & $8.67^{\mathrm{a}} \pm 0.63$ & $8.81^{\mathrm{a}} \pm 0.31$ & $9.14^{\mathrm{a}} \pm 0.35$ & $8.83^{\mathrm{a}} \pm 0.26$ \\
NFE & $23.59^{\mathrm{b}} \pm 1.85$ & $29.75^{\mathrm{a}} \pm 2.69$ & $22.36^{\mathrm{b}} \pm 0.79$ & $28.49^{\mathrm{a}} \pm 0.38$ & $23.75^{\mathrm{b}} \pm 1.57$ \\
\hline
\end{tabular}

abcd Means with different superscripts(s) in the same row differ significantly $(\mathrm{P}<0.01)$

\section{Discussion}

The highest cell number $\left(136.30 \times 10^{5} / \mathrm{ml}\right)$ of Scenedesmus obliquus grown in BBM was significantly $(\mathrm{P}<0.05)$ higher than that of grown in all other treatments. Optical density showed similar trend like cell number as because optical density is directly related to cell number (Khan, 2003). The chlorophyll

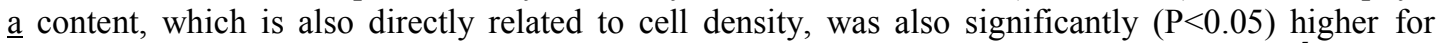
$\operatorname{BBM}(6.14 \mathrm{mg} / \mathrm{l})$ than all other treatments. On the other hand cell density $\left(97.05 \times 10^{5} / \mathrm{ml}\right)$ and chlorophyll a $(5.52 \mathrm{mg} / \mathrm{l})$ grown in $2.5 \%$ SFWM were significantly $(\mathrm{P}<0.05)$ higher than that of grown in other concentrations. Martinez-Jeronimo and Espinosa-Chavez (1994) recorded 30.0x105 cell $/ \mathrm{ml}$ when cultured Scenedesmus incrassathulus in BBM in a laboratory scale system, which is very less than present study. On the other hand Alam (2004) found cell density $109.73 \times 10^{5}$ to $197.33 \times 10^{5} / \mathrm{ml}$ and chlorophyll a content 4.63 to $7.83 \mathrm{mg} / \mathrm{l}$ when cultured Scenedesmus obliquus in the same media with control BBM. He found significantly $(\mathrm{P}<0.05)$ higher cell density and chlorophyll a content for $2.5 \%$ SFWM than other concentrations, which supported the present findings. These findings indicate that $2.5 \%$ SFWM is better for culture of Scenedesmus obliquus than other concentrations. Specific growth rate (SGR, $\mu \mathrm{g} /$ day) of cell and chlorophyll a were found in the range of 0.32 to 0.41 and 0.33 
to 0.41 respectively, for all the treatments. Khan (2003) found SGR of cell and chlorophyll a 0.36 to 0.39 and 0.37 to 0.41 respectively, when cultured Chlorella vulgaris in BBM and sugar mill effluent media. Habib (1998) found SGR of Chlorella vulgaris 0.33 to 0.45 and 0.30 to 0.40 on the basis of cell and chlorophyll a respectively, when cultured in NPK and different concentrations of standard Malaysian rubber effluent (SMRE) media. These findings are more or less similar to the present study. Total biomass was recorded in the range of 181.57 to $411.16 \mathrm{mg} / \mathrm{l}$ which also some how supported the findings of Habib (1998). The $\mathrm{pH}$ range (7.03 to 8.07) of the study supported the range reported by Ukeles (1973). The range of dissolved oxygen was 3.09 to $5.21 \mathrm{mg} / \mathrm{l}$ during the whole culture period, which is supported by Miah et al. (1999); Alam et al. (2003). Light intensity was maintained 2136.28 to $2176.34 \mathrm{lu} / \mathrm{m}^{2} / \mathrm{s}$ during the culture period, which agreed with the range of Singha (2001); Karmakar et al. (2001).

The content of both $\mathrm{PO}_{4}-\mathrm{P}$ and $\mathrm{NO}_{3}-\mathrm{N}$ showed an decreasing trend with the age of culture up to the $10^{\text {th }}$ day of culture when the growth was at the maximum level for all the treatments. Similar findings were recorded by Hussain (2001); Alam et al. (2003) in culture of Chlorella sp. Ammonia-nitrogen $\left(\mathrm{NH}_{3}-\mathrm{N}\right)$ and nitrite nitrogen $\left(\mathrm{NO}_{2}-\mathrm{N}\right)$ were found minimum at the beginning of culture and showed an increasing trend with the age of culture, which was supported by Khan (2003) where he cultured $C$. vulgaris in normal molasses media.

The protein percentage of Scenedesmus obliquus grown in BBM and 2.5\% SFWM showed insignificant $(\mathrm{P}<0.05)$ variation. On the other hand protein, and ash of $S$. obliquus grown in $2.5 \%$ SFWM was significantly $(\mathrm{P}<0.05)$ higher than that of other concentrations of SFWM. Crude lipid was also significantly $(\mathrm{P}<0.05)$ higher for $2.5 \%$ SFWM than that of all other treatments. Crude fiber and moisture showed insignificant $(\mathrm{P}<0.05)$ variation among all the treatments. So, it may be concluded that $S$. obliquus grown in $2.5 \%$ SFWM and BBM is nutritionally rich, which is supported by Geldenhuys et al. (1988). Further study with increasing concentration of SFWM is required as the growth increases with concentration. It is to be found out the concentration where growth show decreasing trend with increasing concentration and nutritional quality of the algae falls.

\section{Conclusion}

Among the three different concentrations of the SFWM 2.5\% showed the best performance in respect of cell number, chlorophyll- $a$, SGR, total biomass and nutrient content. The content of protein, lipid, ash and crude fiber was found $34.56 \%, 16.13 \%, 12.0 \%$ and $6.39 \%$, respectively in $2.5 \%$ SFWM. This study proved the feasibility of SFWM as a Scenedesmus culture media. It is also revealed from this study that as this is an inexpensive algal culture media it can be broadly used in Bangladesh where culture media are expensive and largely unavailable.

\section{Literature Cited}

Alam, M. J. 2004. Growth performance of Scenedesmus obliquus cultured in sweetmeat factory waste media. M.S. Thesis submitted to the department of Fisheries Management, Bangladesh Agricultural University, Mymensingh. pp. 71.

Alam, M. M. M., Miah, M. I. and Habib, M. A. B. 2003. A study on the feeding responses of a filter feeding Cyclops sp. on various concentrations of Chlorella sp. Pakistan J. Sci. and Res. 46(50) : 258-267. 
Bang. J. Anim. Sci. 2008, 37 (1)

Clesceri, L. S., Greenberg, A. E. and Trussell, R. R. 1989. Standard Methods for the Examination of Water and Wastewater. American Public Health Association, American Water Works Association and Water Pollution Control Federation; New York. USA, pp. 92-1110.

Gallardo, P. P., Alfonso, E., Gaxiola, G., Soto, L. A. and Rosas, C. 1995. Feeding schedule for panaeus setiferus larvae based on diatoms (Chaetoceros ceratosporum), flagellates (Tetraselmis chuii) and artemia nauplii. Aquaculture $131: 239-252$.

Geldenhuys, D. J., Walmsley, D. J. and Tofrien, D. J. 1988. Quality of algal material produced on a fertilizer-tap water medium in outdoor plastic enclosed systems. Aquaculture, $68:$ 157-164.

Habib, M. A. B. 1998. Culture of selected microalgae in rubber and palm oil effluents and their use in the production of enriched rotifers. Doctoral Thesis, University of Putra. Malaysia, pp. 539.

Habib, M. A. B., Yusoff, F. M., Phang, S. M., Ang, K. J. and Mohamed, S. 2003. Culture and nutritional value of Moina micrura Pallas fed on Chlorella vulgaris grown in digested palm oil mill effluent. Asian Fish. Sci., 16(3) : 253-261.

Hemerick, G. 1973. Culture Methods and Growth Measurements of Mass Culture. In : Stein, J. R. (ed.) Handbook of Phycological Methods. Cambridge University Press Publication, Cambridge, UK, pp. 255-266.

Horwitz, W. 1984. Official Methods of the Analysis of the Association of Official Analytical Chemists ( $14^{\text {th }}$ ed.). Association of Official Analytical Chemists; Washington DC, USA, pp. 1018.

Hossain, M. I. 2001. Culture of Chlorella elipsoidea in inexpensive medium. M.S. Thesis submitted to the department of Fisheries Management, Bangladesh Agricultural University, Mymensingh. pp. 78.

Karmaker, P. K., Shajahan, M., Miah, M. I. and Habib, M. A. B. 2001. Culture of microalgae (Chlorella ellipsoidea) in various concentrations of ripe and unripe bean seed powder media. Bangladesh J. Fish., 24 (1-2) : 93-99.

Khan, A. I. A. N. M. 2003. Culture of Live Food Organisms in Sugarcane Industry Waste and their Use as Food for Clarias batrachus Fry. Ph.D. Thesis submitted to the Department of Aquaculture, Bangladesh Agricultural University, Mymensingh, Bangladesh, pp. 89.

Martinez-Jeronimo, F. and Espinosa-Chavez, F. 1994. A laboratory-scale system for mass culture of fresh water microalgae in polyethylene bags. J. Appl. Phycol., 6 : 423-425.

Miah, M. I., Rahman, M. A., Alam, M. M. and Rahman, M. S. 1999. A study on the feeding responses of Diaphenosoma sp. in different concentrations of cultured Chlorococcum sp. Bangladesh J. Aquaculture. $21: 69-78$.

Rodhe, W. 1978. Algae in culture and nature. Mitteilungen International Vereinigung Limnol., 21 : 7-20.

Shelef, G., G. Oron and Moraine, R. 1978. Economic aspects of microalgae production on sewage. Archiv für Hydrobiologie beiheft Ergednisse der Limnologie, $11: 280-294$.

Singha, S. K. 2001. Evaluation of press mud and sugarcane mill effluent as culture media for the growth of Chlorella vulgaris. M.S. Thesis, Dept. of Aquaculture, BAU Mymensingh, 38 pp.

Ukeles, R. 1973. Continuous culture- a method for the production of unicellular algal foods. In: Stein, J. R. (ed.). Handbook of Physiological Methods, Culture Methods and Growth Measurements. Cambridge University Press Publication, Cambridge, UK, pp. 233-256.

Vymazal, J. 1995. Algae and Element Cycling in Wetlands. CRC Press, Inc. Boca Raton, Florida, USA, pp. 689.

Yamaguchi, K. 1997. Recent advances in microalgal bioscience in Japan, with special reference to utilization of biomass and metabolites : a review. J. Appl. Phycol., $8: 487-502$.

Zar, J. H. 1984. Biostatistics. Prentice-Hall, Inc., Englewood Cliffs, New Jersey, USA, pp. 718. 